\title{
The Utilization of Search Engine as a Learning Resource by Early Childhood Education Teachers
}

\author{
Rizki Surya Amanda, Yoyon Suryono \\ Yogyakarta State University, Yogyakrta, Indoensia \\ e-mail: rizki.surya2016@student.uny.ac.id
}

\begin{abstract}
In the digital era, teachers are required to utilize existing technology as a learning resource to develop and deepen the mastery of learning materials. This study aims to find out how much the use of search engines as learning resources by teachers of early childhood education. This research uses quantitative descriptive research. The research subjects consisted of 59 teachers in Bukit Kerman district Kerinci regency Jambi province. Data is taken using a questionnaire distributed through the Google Form. The data analysis technique used in this study is a descriptive analysis technique using percentages. The results showed that the level of utilization of search engines as one source of learning is in the moderate category. This means that the teacher has benefited enough from the search engines to find references to learning in school. As many as $61 \%$ of teachers are in the moderate category, $22 \%$ are in the high category, and $17 \%$ are in a low category.
\end{abstract}

Keywords: Internet, Search engine, Learning resource, Teacher

\section{INTRODUCTION}

Globalization era, various information is easy and fast to get. People no longer have to read books or newspapers to get cooled information. Information can be obtained from electronic media or print media, even print media such as newspapers also have applications to make it easier for readers to access the news they convey.

Sophisticated information technology needs to be utilized. Despite having positive and negative sides, the sophistication of information technology makes a significant impact on everyday life. One of the most significant changes is the existence of the internet. Through the internet, people can exchange information and get whatever content they want. The Internet is an abbreviation for Inter-Connected Network which is widely used as a tool for finding information, communicating, and for social networks.

According to Aji Supriyanto (2005: 336), the internet is a global computer network, which consists of millions of computers connected to each other with the same protocol to share information together. The ease of using the internet is accessible anytime, anywhere, and anywhere. Information accessed can be in the form of text, graphics, sound, or video. The development of the internet is very fast and wide so that it can be accessed all over the world. This makes it possible to exchange information with people around the world.

The presence of the internet for now has become a necessity for anyone, not limited to business people, but this has also penetrated in various fields including education. This internet network can serve all the needs of its users including educational world, which is connected from wireless and optical electronic networking technologies (Sharrif \& Kosmin, 2012). The internet can be used by schools, teachers, and students. In terms of educators, the internet can be used as access to information, besides educators can also use the internet to look for reference materials for materials to be given to their students. The existence of the 
Internet opens a source of information that was previously difficult to access. Access to information sources is no longer difficult. The library is an expensive source of information. The existence of the Internet allows someone in Indonesia to access libraries in domestic and foreign universities (digital libraries).

Internet in education has many advantages. The internet can be used as a means of finding information, making it easier to find references, learning tools, providers of additional learning resources, encouraging mastery of foreign languages, means of distance education, a place to store information, and other benefits. Even so the internet has weaknesses. The weakness of the internet in Indonesia is that internet infrastructure is still limited and expensive, limited funds, and our reading culture is still weak. Not all regions are accessible to the internet and not all schools have internet facilities. This is where the challenge is how to develop learning models through the internet. That way the teachers will not be difficult when faced with the internet that stores all information and as a source of learning for students and teachers in the classroom.

In the digital era, teachers are required to be able to use and utilize existing technology, including using the internet to support learning. The Internet provides various information that can be used by teachers to expand and deepen their insight as teachers. The presence of the internet can help teachers easily obtain information to enrich the material to be delivered in class. The internet can also expand and support knowledge and improve teacher quality so that it is expected to improve the quality of learning. Geladze (2015) says various types of internet resources enrich teacher and student activities. Observations have shown that the use of information technology changes attitudes toward learning.

In general, the reference that is often used by a teacher is a textbook or module that has been provided by the government. Not all teachers get modules or books easily. Therefore, other sources are needed that are easier and faster to obtain to enrich the source of information for teachers. According to Adri (2007), the use of the internet network as a source and means of learning can be implemented as follows:

1. Browsing is a general term used when you want to surf the web. Browsing or surfing is an activity to view or search for information on the web. Many people deliberately make web pages in a site that can be accessed by anyone freely. Through browsing the teacher can find web pages that provide information to support a career as a teacher.

2. Resourcing is to make the internet a source of teaching. Resourcing is meant here is to make the internet as a medium of learning, in the meaning of the role of the internet as a storehouse of information used to obtain data and information related to learning resources, in this case information related to the site address to be visited as a learning resource is known in advance through the information provided in the handbook and other examples.

3. Searching is the process of finding learning resources to complement the material that will be delivered to students. In this case, all information related to the source of the information is unknown, so it uses search engines. Search is one of the facilities available on the application to find the information we want. Search engines accommodate a database of sites from all over the world that number billions of web pages. Only by entering the keyword, the search process will be carried out, and the search engine will display several site links along with a brief description.

4. Consulting and communicating. Consultation via the internet can be done via email. E-mail can be used as a learning media, media consultation and communication between educators, students and parents. Consultation via e-mail can be done anywhere and anytime. To communicate educators can use social networks such as WhatsApp, Facebook, and other social networks. The internet can be used as a source and learning media.

In educational world, the internet is useful as a source and media for learning. The use of the internet as a learning resource is intended to improve the understanding of educators in seeking reference material for learning and to improve the ability and professionalism in carrying out teaching and learning activities. While the use of the internet as a learning medium conditions teachers to prepare teaching materials by utilizing the internet. In early childhood education, teachers can access content related to early childhood education. The content obtained from the internet can be in the form of pictures, songs, videos, and other things that can support the improvement of the quality of learning in the classroom. As is known early childhood learning uses a lot of pictures, songs, and movements. The existence of the internet is certainly 
a useful source of reference for teachers to carry out teaching.

Teaching and material resources are several factors that can assist in the implementation of effective teaching and learning (Syed Ali, 2014). Early childhood teachers need innovative ideas from the internet to make learning more innovative. The Association for Educational Communications and Technology in Susilana \& Riyana (2008) says the source of learning is everything or power that can be utilized by the teacher, both separately and in combination, for the sake of teaching and learning with the aim of increasing the effectiveness and efficiency of learning objectives. Learning resources can be grouped into two parts, namely: (1) Sources of learning that are intentionally planned, namely all sources that have been specifically developed as a component of the instructional system to provide targeted and formal learning facilities; and (2) Learning resources that are used, namely learning resources that are not specifically designed for learning purposes but can be found, applied, and used for learning purposes, are mass media. Education is basically an information communication process from educators to students who have educator elements as a source of information, the media as a means of presenting ideas, ideas and material as well as the students themselves.

Mclsaac and Gunawardena (1976) explained that learning resources that can be used for learning needs are very diverse in types and shapes. Learning resources is not only in the form of printed materials such as textbooks. Good teachers can also take advantage of other learning resources such as educational radio, television, computers, e-mail, interactive video, satellite communication, and multimedia computer technology in an effort to increase interaction and feedback with students. Seels and Richey (1994) explain that learning resources are all supporting sources for learning activities, including support systems and materials and learning environments. Learning resource is not only tools and materials used in learning, but also include people, budgets, and facilities. Learning resources can include whatever is available to help someone learn.

According to Ghufron in Parji (2011: 102), the exposure of information material through mass media, both electronic and printed can also be used as learning resources. Sadiman (2001: 94) states that changes and developments that apply quickly, require the provision of actual, information-rich and easily accessible learning resources. The internet is a technology that has provided a strong foundation for the creation of a rich and flexible learning environment and is able to fulfill education and training. The internet is categorized as a learning resource that is able to channel a variety of scientific and non-scientific information to everyone anywhere and anytime without thinking of the limits of space and time. This statement shows that the internet as a source of learning indirectly assists the teacher in the learning process.

Learning resources are very important components in the learning process so that learning activities become effective and efficient in achieving goals. In language, learning resources are anything that is a source of information in learning, which can be in the form of experience, teachers, books, computers, the internet, or anything that can be used as a learning resource. Formally in learning in school learning resources can be in the form of media and / or teaching aids used by the teacher in the learning process with students.

The internet is needed as a learning resource because of the incomplete books owned by the teacher and the high cost of buying books or other printed media used in learning. This is a factor that can hinder the teacher. For this reason, the internet is one of the effective and efficient learning resources and access costs are also relatively cheap. Even though the teachers understand that the learning strategy by utilizing various learning resources is very supportive or helps to increase the level of students' mastery of the subject matter, but in reality, there are still many teachers who organize learning activities without being supported by various learning resources (Siahaan dalam Ekayana, 2015).

The advantage of the internet as a learning resource is that it can access data exchange quickly between users. The internet also contains up to date information. Search results from the internet directly focus on the sub-topics that will be searched and can be accessed in many places because of the large number of internet service providers.

One of the internet tools most frequently used by internet users around the world is the Search Engine. In educational world, search engines can facilitate teachers in finding learning resources. Besides that, Search engines have advantages in terms of practicality compared to other learning sources. Through search engines teachers can find 
information what they want to get by typing related keywords. Search engines allow teachers to become alternative learning resources.

Search is one of the facilities available on search engines to find the information needed. In this case, all information related to the source of the information is unknown, so it uses search engines. Search engines accommodate a database of sites from all over the world that number billions of web pages. Many search engine applications offered by certain sites on the internet, which are popular include google, yahoo, altavista and other sites.

Google is the most widely used search engine service. Google currently has services including web, images, maps, news, books and others that make it easier for us to search any information based on keywords. With searching we can get a lot of learning resources both formal and informal. With Google we can also search for various forms of information sources, including PDF, PPT, images or other forms.

Search engines have offered various facilities so that teachers get a wider source of information. Because the teacher should be able to make the most of this convenience. This study aims to reveal how teachers use search engines as a source of learning. The learning source in question is in the form of subject matter, videos, song, e-books, and other information that can be used as learning resources.

\section{METHOD}

This research is quantitative descriptive. According Sukardi (2003: 162) descriptive research is a research method that attempts to describe the object or subject under study in accordance with what it is, with the aim of systematically describing the facts and characteristics of the object under study precisely. This study aims to describe the use of search engines by early childhood education teachers as learning resources. This study is classified as an ex post facto study where events have occurred without treatment. Darmawan (2013: 40) said that expose facto research is a systematic empirical investigation where researchers do not have direct control of variables.

The population used in this study were teachers of early childhood education in the Bukit Kerman district Kerinci regency, Jambi Province with a total of 59 teachers. The sampling technique used is saturated sampling. Thus, the population is sampled.

The variables examined in this study are about the use of search engines by early childhood education teachers. The use of search engines as learning resources consists of obtaining information, searching for pictures, searching e-books, searching for materials, searching and downloading videos, download songs and children's song lyrics, look for story references or fairy tales, look for references and examples of learning media, get activity ideas, and look for more varied class arrangement references.

Data collection techniques used in this study are questionnaires. The questionnaires were distributed in the form of a closed questionnaire with 10 statements regarding the use of search engines by teachers of early childhood education. The questionnaire uses a Likert scale with 4 answer choices which are always, often, rarely and never.

The data analysis technique used is descriptive analysis technique. The collected data will be analyzed descriptively by tabulation and percentage. Data were analyzed and categorized into three categories: high, moderate, and low.

\section{RESULT AND DISCUSSION}

\subsection{Result}

The completed questionnaire was then analyzed using descriptive analysis. Scores are categorized into three, namely high, medium, and low. Previously the scores of each item were summed and compared with the ideal score obtained. The description of the use of search engines by teachers of early childhood education in Bukit Kerman District can be seen in table 1 below 
Table 1. Score each item

\begin{tabular}{llll}
\hline \hline No & Statement & $\begin{array}{l}\text { Empirical } \\
\text { score }\end{array}$ & Percentage \\
\hline 1 & obtaining information & 176 & $74,6 \%$ \\
\hline 2 & searching for pictures & 187 & $79,2 \%$ \\
\hline 3 & searching e-books & 122 & $51,7 \%$ \\
\hline 4 & searching for materials & 182 & $77,1 \%$ \\
\hline 5 & $\begin{array}{l}\text { searching and } \\
\text { downloading videos }\end{array}$ & $55,5 \%$ \\
\hline 6 & $\begin{array}{l}\text { download songs and } \\
\text { children's song lyrics, }\end{array}$ & $68,6 \%$ \\
\hline 7 & $\begin{array}{l}\text { look for story } \\
\text { references or fairy tales }\end{array}$ \\
\hline 8 & $\begin{array}{l}\text { Look for references and } \\
\text { examples of learning } \\
\text { media }\end{array}$ & $58,5 \%$ \\
\hline 9 & get activity ideas & $75,4 \%$ \\
\hline 10 & $\begin{array}{l}\text { Look for more varied } \\
\text { class } 185 \\
\text { references arrangement }\end{array}$ & $70,3 \%$ \\
\hline & \multicolumn{2}{l}{$78,4 \%$} \\
\hline
\end{tabular}

Based on table 1, item number 2 obtained the highest percentage of $79.2 \%$, while item number 3 got the lowest percentage of $51.7 \%$. Item number 1 got percentage of $74.6 \%$, item number 4 got percentage of $77.1 \%$, item number 5 got percentage of $55.5 \%$, item number 6 got percentage of $68.6 \%$, item number 7 got percentage of $58.5 \%$, item number 8 got the percentage of $75.4 \%$, item number 9 got the percentage of $70.3 \%$, and item number 10 got the percentage of $78.4 \%$.

From the distribution of data obtained, the overall score is presented in the list of frequency distributions with the number of 6 class and class length 2 . The distribution of frequency distribution is presented in Figure 1.

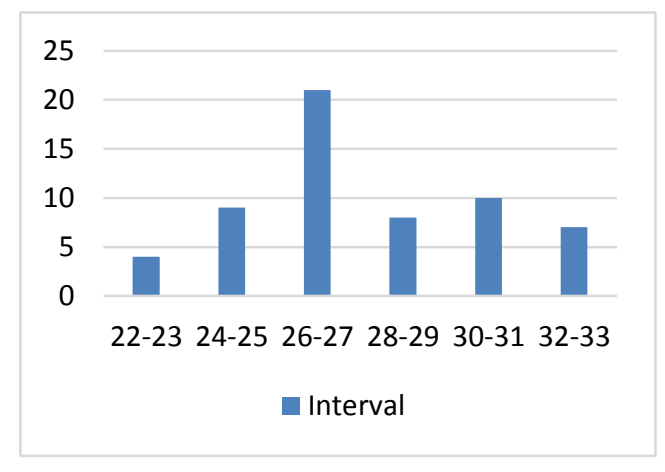

Figure 1. Frequency of search engine utilization scores
Table 2. Score category

\begin{tabular}{llll}
\hline \hline Category & Score & Frequency & Percentage \\
\hline High & $X>30,365$ & 13 & $22 \%$ \\
\hline Moderate & $\begin{array}{l}24,895<X \\
30,365\end{array}$ & & $61 \%$ \\
& $X<24,895$ & 10 & $17 \%$ \\
\hline Low & $\mathrm{X}$ & \\
\hline \hline
\end{tabular}

Based on the results of data analysis, it was found that the use of the search engine by ECE's teachers was in the medium category. This is seen from 36 or $61 \%$ of teachers in the medium category. Teachers who are in the high category are $22 \%$ or 13 people, while those in the low category are 10 people or $17 \%$.

\subsection{Discussion}

The analysis shows that the use of search engines by PAUD teachers is in the medium category. This means that some teachers have been good enough to use search engines to support and expand learning resources. Teachers need search engines to access learning resources such as pictures, videos, songs, and other methods needed to support the learning process. Suharno Widi Nugroho (2006: 19) said it would be very helpful if learning used the internet as a learning resource for teachers.

The intended use is to utilize and benefit from search engines to support learning success. So the use of the internet as a learning resource is someone's activities intentionally using everything contained in the search engines to obtain some information, knowledge material, and interesting content content to add experience and creativity in the process of early childhood learning. The teacher has been good enough in utilizing the search engine to obtain information that supports the learning process, looking for materials related to early childhood education, downloading songs and children's song lyrics, looking for stories or fairy references that will be conveyed in class, looking at references and examples of learning media, get ideas for activities to be carried out in class and to see more varied class arrangement references.

The findings indicate that teachers access the search engines to find images related to the learning theme to get the highest score of $79.2 \%$ of the ideal score. As many as 45 teachers answered they often access search engines to find images related to the theme or learning material. Early childhood learning uses many images both as learning media and for 
child worksheets. Teachers usually use pictures to convey learning materials or themes to children. In addition images are also widely used in early childhood learning activities such as coloring. These results illustrate that teachers need search engines to get the desired images easily.

The findings also show teachers accessing search engines to find e-books to get the lowest percentage. As many as 21 teachers answered they had never and 13 teachers answered they rarely accessed search engines to find e-books. These results indicate that teachers are less than optimal in using search engines to find e-books. Electronic books or digital books are electronic versions of books. If the book generally consists of a collection of papers that can contain text or images, the electronic book contains digital information that can also be in the form of text or images. Through search engines the teacher can find many e-books related to ECE material that are easily available without expensive costs.

Another item that gets a low score is the use of search engines to search for and download videos related to learning themes. A total of 36 teachers answered that they rarely download videos related to the subject matter. These results indicate that teachers also have not maximally used the search engine to search and download videos. Learning resources through video are needed by the teacher. Through search engines teachers can access videos related to early childhood learning such as gymnastics videos, motion and songs, stories and other videos that can support early childhood learning.

The teacher has used the search engine to obtain information related to early childhood education. A total of 42 teachers answered they often access information through search engines. In addition teachers also access search engines to see information related to career development as a teacher, such as regarding teacher competency testing, information from the government regarding teacher data, and other information related to teacher career development.

Search egine helps teachers to search for early childhood education materials. As many as 48 teachers answered that they often access search engines to obtain ECE materials. The material in question is material obtained through blogs, scientific articles, and writings relating to early childhood learning.
With practical facilities, search engines can be used to download songs. As many as 44 teachers answered they often download children's songs related to the theme. Early childhood learning always uses songs in the learning process. This is to motivate children to be ready to learn.

As many as 42 teachers answered they often use search engines to see learning media references. Teachers need to see various learning media used by other schools. Children need varied learning so they don't get bored.

Early childhood do a lot of activities in the learning process. Therefore the teacher must think about various activities. As many as 42 teachers answered they often use search engines to get ideas for learning activities to be applied in the classroom. Classroom arrangement is one of the requirements for successful learning activities in the ECE class. The teacher should arrange the class interestingly so that the child is at home in learning. A total of 49 teachers claimed to often use search engines to see more varied class arrangement references.

As many as 31 teachers answered often and 24 teachers answered always using search engines to find stories to be delivered in class. Learning methods by telling stories are often applied in ECE learning. Through search engines the teacher can find references to various interesting stories or stories. This gives convenience because not all stories can be found in the book.

The need for the internet cannot be avoided. Search engines provide useful content to support the implementation of learning easily and without expensive costs. Azhar Arsyad (2010: 26) said the use of the internet is very important to support learning. ECE teacher over the Internet can obtain references and sources of more extensive and varitif for use in learning.

The internet is not a substitute for the education system. Internet presence is more supplementary and complementary. The conventional method is still needed, only it can be modified to another form. In early childhood education conventional learning resources are very necessary, but teachers must also have other references in addition to expanding learning resources.

\section{CONCLUSION}

Based on the results of research conducted on the use of search engines by early childhood 
education teachers in Bukit Kerman district was good enough, but still had to be improved. Teachers need guidance and facilities especially in downloading videos and e-books that are still not optimal. With the results of this study it is expected that the teacher can maximize the use of the engine system to support learning.

Seeing the huge potential of the internet that can be used for the benefit of learning, teachers should be able to make it as a source of learning and use it in teaching and learning activities. The teachers are also expected to be able to plan the use of the internet in teaching and learning activities on a regular basis so that children get learning experiences from learning resources outside the teacher that relate to the subject matter. The role or support of the Principal as the school manager is expected to facilitate the use of internet media for learning and at the same time provide opportunities for teachers to attend training on the development and use of the internet for learning purposes.

\section{REFERENCES}

[1] Aji, S. (2005). Pengenalan Internet dan Jaringan Komputer. Jakarta: PT. Elexmedia Computindo.

[2] Adri, Muhammad. (2007). Makalah dalam rangka Semiloka Pengembangan Model Pembelajaran Berbasis Teknologi Informasi. Pemanfaatan Internet sebagai Sumber Pembelajaran. Padang: Fakultas Teknik Universitas Negeri Padang.

[3] Azhar Arsyad. (2010). Media Pembelajaran. Jakarta: Raja Grafindo Persada.

[4] Darmawan. (2013). Metode Penelitian Kuantitatif. Bandung: Remaja Rosdakarya.

[5] Ekayana, A. A. G. (2015). Pemanfaatan internet sebagai salah satu sumber belajar siswa dan guru di jurusan teknik elektronika. Jurnal Pendidikan Teknologi dan Kejuruan, 12(2).

[6] Geladze, D. (2015). Using the Internet and Computer Technologies in Learning/Teaching Process. Journal of Education and Practice, 6(2), 67-69. Retrieved from http://iiste.org/Journals/index.php/JEP/article/vi ew/19402\%5Cnhttp://iiste.org/Journals/index.ph p/JEP/article/viewFile/19402/19585

[7] Mclsaac M. S. \& Gunawardena. (1996) Handbook of Research for Educational Communications and Technology. New York: AECT.

[8] Parji, P. (2016). Strategi Pembelajaran Pendidikan Moral pada Era Teknologi Informasi. Jurnal Ilmu Pendidikan, 9(2).

[9] Sadiman, A. S. (2009). Media pendidikan: pengertian, pengembangan, dan pemanfaatannya. Jakarta: PT. Raja Grafindo Persada.

[10] Seels, Barbara \& Richey, R.C (1994). Instructional Technology: The Definition and Domains of the Field Washington, DC: AECT

[11] Sharrif, S., \& Kosmin, R. (2012). Regulating content in broadcasting, media and the internet: a case study on public understanding of their role on self-regulation. International Journal of Humanities and Social Science, 2(23).

[12] Suharno Widi Nugroho. (2006). Bermain Internet. Jakarta: PT Anaksaleh Pratama

[13] Sukardi. (2003). Metodologi Penilitian Pendidikan. Jakrata: Bumi Aksara.

[14] Susilana, R., Si, M., \& Riyana, C. (2008). Media Pembelajaran: Hakikat, Pengembangan, Pemanfaatan, dan Penilaian. CV. Wacana Prima.

[15] Syed Ali, s. K. bin. (2014). Teachers planning and preparation of teaching resources and materials in the implementation of Form 4 Physical Education curriculum for physical fitness strand. Turkish Journal of Sport and Exercise, 16(1), 67-67. https://doi.org/10.15314/TJŚE.201416165 